\title{
PENGARUH MODEL PEMBELAJARAN DAN TINGKAT KEMAMPUAN PERSEPTUAL MOTORIK SISWA TERHADAP HASIL BELAJAR KETERAMPILAN
}

\author{
Achmad Nuryadi \\ Dosen Prodi PKO - FKIP - Universitas PGRI Adi Buana Surabaya \\ caknuryadi73@gmail.com
}

\begin{abstract}
Abstrak
Peranan model pembelajaran dalam penyelenggaraan proses pendidikan jasmani di jenjang sekolah khususnya di sekolah dasar sangat menentukan keberhasilan anak dalam mencapai hasil yang diinginkan. Model pembelajaran merupakan acuan yang memuat langkah-langkah prosedural yang digunakan pada kondisi tertentu untuk mencapai hasil pembelajaran yang diinginkan.

Selama ini model pembelajaran untuk pendidikan jasmani lebih diarahkan kepada model tugas gerak dalam bentuk teknik gerakan yang standar atau baku. Model ini mengakibatkan anak pada tingkat sekolah dasar menjauhi dan bosan pada kegiatan pendidian jasmani karna tidak sesuai dengan kebutuhan dan tuntutan perkembangan jasmani anak. Model ini dinamakan model pembelajaran tradisional, dimana guru yang lebih banyak berperan dalam kegiatan belajar mengajar pendidikan jasmani. Oelh karena itu dibutuhkan inovasi dalam model pembelajaran pendidikan jasmani dengan memodifikasi teknik gerak yang disesuaikan dengan kebutuhan perkembangan anak. Model ini diancang untuk mempermudah anak fdalam menguasai gerak dasar suatu olahraga permainan mulai dari tingkat yang sederhana menujun ke tingkat yang kompleks.

Di sisi lain, kemampuan perseptual motorik anak merupakan bagian yang penting dan terintegrasi dengan kemampuan anak memahami teknik-teknik gerak. Kemampuan perseptual motorik merupakan potensi anak yang dapat membantu anak tersebut memproyeksikan berbagai rangsangan yang masuk melalui indera penglihatan untuk menentukan bentuk gerak dan untuk merespon rangsangan tersebut.

Penelitian ini bertujuan untuk menentukan pengaruh utama dan pengaruh interaksi variabel perlakuan (model pembelajaran) terhadap prestasi belajar keterampilan teknik dasar permainan bola basket siswa sekolah dasar. Manfaat dari penelitian ini terbagi menjadi dua, yaitu 1) manfaat secara teoritis yang terkait dengan kebijakan di bidang pendidikan, dan 2) manfaat yang bersifat praktis untuk dipakai dalam proses pembelajaran pendidikan jasmani di sekolah dasar.

Penelitian ini merupakan penelitian kuasi eksperimen dengan mempergunakan rancangan versi nonequivalent control group design. Sampel dari penelitian ini adalah siswa sekolah dasar/ madrasah ibtidaiyah pada dua sekolah yang berbeda. Pemilihan sampel menggunakan teknik sampel kelompok acak (random), dengan sampel kelas lima dan enam sebanyak 40 orang. Pengolahan data dilakukan dengan menggunakan teknik analisis varian (anava) dua jalur $2 \times 2$.
\end{abstract}

Kata kunci: Model Pembelajaran, Tingkat Kemampuan Perseptual, Hasil Belajar Keterampilan

\section{Pendahuluan}

Model pembelajaran dalam melaksanakan proses pendidikan jasmani di sekolah, khususnya di sekolah dasar, memainkan peran penting dalam keberhasilan siswa. Model pembelajaran adalah petunjuk yang memiliki langkah-langkah prosedural yang digunakan dalam kondisi tertentu untuk mencapai prestasi belajar yang diinginkan. Sejauh ini, model pembelajaran pendidikan jasmani lebih disukai untuk gerakan model tugas dalam teknik gerakan standar. Model ini menyebabkan siswa di sekolah dasar mulai bosan dengan aktivitas pendidikan jasmani karena tidak sesuai dengan kebutuhan dan perkembangan fisik siswa. Model ini disebut pembelajaran tradisional, di mana guru menempatkan lebih dari siswa dalam kegiatan belajar mengajar. Jadi kita mulai berpikir suatu inovasi yang diperlukan dalam model pendidikan jasmani dengan memodifikasi teknik gerakan yang sesuai dengan kebutuhan perkembangan siswa. Hal ini dirancang untuk memudahkan siswa dalam menguasai gerakan 
dasar olahraga, mulai dari tingkat sederhana untuk satu kompleks.

Di sisi lain, keterampilan perseptual motorik dari siswa merupakan bagian yang sangat penting dan terintegrasi dengan keterampilan siswa untuk memahami teknik gerakan. Keterampilan ini adalah potensi siswa yang dapat membantu siswa untuk mencerminkan banyaknya stimulus yang masuk melalui mata untuk menentukan bentuk gerakan dan merespon stimulus.

Penelitian ini adalah untuk mengetahui pengaruh yang menonjol dan efek interaksi variabel tindakan (model pembelajaran) untuk pencapaian teknik dasar bola basket untuk siswayang belajarn di sekolah dasar. Manfaat dari penelitian ini adalah: 1) manfaat teoritis, terkait dengan kebijakan pendidikan dan 2) manfaat praktis, untuk proses kegiatan belajar mengajar pendidikan jasmani di sekolah dasar.

Penyelenggara pendidikan jasmani di sekolah lebih khusus jenjang pendidikan sekolah dasar pertama sangat berpotensi untuk mengembangkan peserta didik ke arah yang optimal. Pendidikan jasmani di sekolah dasar bertujuan untuk mengembangkan anak secara multilateral melalui empat ranah, yaitu ranah jasmani, ranah psikomotor, ranah kognitif, dan ranah afektif (Sukintaka,2004). Walker (2004) menyatakan pendidikan jasmani yang diberikan dengan benar dapat menumbuhkan dasar-dasar tentang kesehatan yang kuat pada anak sekolah dasar dan merupakan langkah awal menuju pribadi dewasa yang sehat. Wuest dan Bucher (1995) menyatakan pendidikan jasmani merupakan proses pendidikan yang bertujuan untuk memperbaiki kerja, dan mengembangkan peningkatan manusia melalui media aktivitas jasmani.

Seorang guru harus memiliki kemampuan dasar untuk melaksanakan tugas belajar yang dikelompokkan dalam tiga bagian, yaitu: (a) kompetensi kognitif, (b) kompetensi sikap, dan (c) kompetensi kinerja (performance). Dalam hal ini, tugas guru adalah menyusun dan merumuskan tujuan yang tepat, memilih dan menyusun bahan pelajaran yang sesuai dengan kebutuhan, minat, dan tahap perkembangan anak, memiliki metode dan media mengajar yang bervariasi serta menyusun program dan alat evaluasi yang memudahkan guru dalam implementasinya. Guru hendaknya mampu memilih dan menciptakan situasi-situasi belajar yang menggairahkan siswa, mampu memilih dan melaksanakan metode mengajar yang sesuai dengan kemampuan siswa, bahan pelajaran dan banyak mengaktifkan siswa, guru juga hendaknya mampu memilih, menyusun dan melaksanakan evaluasi baik untuk mengevaluasi perkembangan atau hasil belajar siswa untuk menilai efisiensi pelaksanaannya itu sendiri. Model pembelajaran modifikasi dalam mata pelajaran pendidikan jasmani diperlukan dengan tujuan agar: 1) siswa memperoleh kepuasan dalam mengikuti pelajaran, 2) meningkatkan kemungkinan keberhasilan dalam berpartisipasi, dan 3) siswa dapat melakukan pola gerak secara benar.

Kemampuan perseptual yang berhubungan dengan gerak tubuh dapat dikategorikan menjadi 5 (lima) macam yaitu: 1) diskriminasi kinestetik, 2) diskriminasi visual, 3) diskriminasi auditori, 4) diskriminasi taktik, dan 5) kemampuan koordinasi (Harrow, 1972).

\section{Definisi Operasional}

1. Model pembelajaran modifikasi adalah perubahan cara belajar dari teknik permainan yang standar dan baku diubah dan disesuaikan dengan tingkat pertumbuhan dan perkembangan anak dan dilakukan dengan pentahapan.

2. Model tradisional adalah model pembelajaran yang dilakukan dengan menggunakan teknik-teknik yang sebenarnya dan baku.

3. Keterampilan teknik dasar bola basket adalah teknik-teknik dasar permainan yang harus dikuasai, seperti teknik dribbling, teknik passing, dan teknik shooting.

4. Pendidikan jasmani adalah suatu proses pendidikan yang ditujukan untuk mencapai tujuan pendidikan melalui aktivitas jasmani/fisik. 
5. Kemampuan perseptual motorik adalah kemampuan individu untuk menerima, menginterpretasikan, dan memberikan reaksi dengan tepat kepada sejumlah rangsangan yang datang.

6. Hasil belajar keterampilan adalah hasil belajar keterampilan teknik dasar permainan bola basket, yaitu teknik dribbling, teknik passing, dan teknik shooting yang ditampilkan melalui unjuk kerja setelah mengikuti kegiatan pembelajaran.

Penguasaan konsep tahap-tahap belajar gerak diperlukan oleh guru pendidikan jasmani karena gerak merupakan alat dalam mempelajari pendidikan jasmani. Dengan penguasaan ini diharapkan dapat menunjang kemampuan guru dalam penyampaian materi pelajaran keterampilan gerak bagi anak. Fitts \& Posner oleh Schmidt (1991), dan Lutan (1988) mengatakan bahwa keterampilan belajar gerak berlangsung dalam tiga fase, yaitu: a) fase kognitif adalah fase yang banyak melibatkan intelektual b) fase asosiasi ditandai oleh semakin efektifnya cara-cara anak melakukan tugas gerak, dan mulai menyesuaikan diri dengan keterampilan yang dilakukan c) fase otomatisasi adalah belajar keterampilan secara otomatisasi tanpa disadari atau dipikirkan sama sekali, anak mencapai rangkaian gerakan melalui latihan yang sungguh-sungguh, dan rentang kesalahan mulai berkurang, pola gerakan semakin sempurna, dan anak melakukan seluruh pola gerakan secara otomatisasi dengan hasil yang memuaskan.

\section{Tujuan Penelitian}

Penelitian ini bertujuan untuk memperoleh fakta tentang model pembelajaran yang efektif dan efisien dalam mata pelajaran pendidikan jasmani khususnya adalah teknik dasar permainan bola basket di jenjang pendidikan sekolah dasar

\section{Desain Penelitian}

Penelitian ini menggunakan kuasi eksperimen dengan rancangan the version of nonequivalent control group design versi faktorial $2 \times 2$. The nonequivalent control group design adalah salah satu rancangan kuasi eksperimen yang paling sering digunakan, terutama ketika tidak memungkinkan atau sulit untuk menetapkan subyek secara random untuk pengelompokan. Peneliti menggunakan kelompok utuh, sehingga situasi ini dengan serta merta menerunkan kekuatan rancangan untuk menetapkan kausal. Hal ini disebabkan karena ada kesangsian tentang kesepadanan (equivalent) kelompok sebelum ekperimen dimulai. Melalui rancangan faktorial $2 \times 2$ yang digunakan, maka dapat ditentukan pengaruh utama dan pengaruh interaksi antara semua variabel.

$\begin{array}{ccc}\text { O1 } & \mathrm{X} 1 & \mathrm{O} 2 \\ \mathrm{O} 3 & \mathrm{X} 2 & \mathrm{O} 4\end{array}$

Gambar 1 Diagram the version of Nonequivalent Control Group Design

(Adaptasi dari Tuckman, 1999)

Keterangan:

O1,3 = pre test tentang keterampilan teknik dasar permainan bola basket

$\mathrm{O} 2,4=$ post test tentang keterampialn teknik dasar permainan bola basket

$\mathrm{X} 1=$ model pembelajaran tradisional

$\mathrm{X} 2=$ model pembelajaran dengan pendekatan modifikasi

------- = kelompok utuh

Variabel dalam penelitian ini berupa variabel bebas (variabel independent) dan variabel terikat (variabel dependent). Variabel independen terdiri atas dua variabel, yakni model pembelajaran, dan kemampuan perseptual motorik. Variabel dependen yang akan diteliti adalah hasil belajar keterampilan berupa nteknik dasar permainan bola basket di sekolah dasar. Selain variabel di atas, masih terdapat variabel-variabel lain yang perlu dikontrol. Variabel-variabel tersebut adalah (1) sarana dan prasarana belajar, (2) sikap dan kesungguhan guru dalam proses penelitian, dan (3) waktu penelitian. Ketiga variabel 
tersebut dapat diasumsikan konstan, sehingga diduga tidak akan memberikan pengaruh yang signifikan terhadap variabel dependen hasil belajar keterampilan teknik dasar permainan bola basket di sekolah dasar.

\section{Populasi dan Sampel}

\section{Populasi Penelitian}

Sumber data utama dalam penelitian ini adalah Madrasah Ibtidaiyah setingkat Sekolah Dasar yang ada di Kecamatan Sidoarjo Kabupaten Sidoarjo. Madrasah Ibtidaiyah yang dipakai sebagai populasi penelitian ini adalah Madrasah Ibtidaiyah Darul Ulum Sarirogo Sidoarjo dan Madrasah Ibtidaiyah Nahdatul Ulama Sumput Sidoarjo kelas 5.

2. Sampel Penelitian

Sampel penelitian ini adalah siswa kelas 5 dari 2 sekolah yang berbeda, yaitu Madrasah Ibtidaiyah di kecamatan Sidoarjo Kabupaten Sidoarjo. Dipilihnya kelas lima siswa sekolah dasar karena dianggap sudah cukup besar dan mampu melaukan tugas gerak dalam penelitian ini. Pemilihan sampel penelitian dilakukan dengan teknik random, di mana sekolah yang ada akan dipilih sampel secara acak. Dari sampel tersebut akan dibagi kelas yang menggunakan model pembelajaran tradisional dan ada yang menggunakan model pembelajaran modifikasi. Jumlah sampel yang akan dipakai dalam penelitian ini adalah 40 orang di masing-masing sekolah.

\section{B. Instrumen Penelitian}

Data penelitian ini dikumpulkan melalui langkah-langkah sebagai berikut; (1) melakukan tes kemampuan motorik, (2) melakukan tes awal, (3) melaksanakan perlakuan (eksperimen), dan (4) melakukan pasca tes (tes akhir) kepada siswa pada semua kelas sampel setelah pelaksanaan perlakuan (eksperimen).

Tabel 1.1. Prosedur Pelaksanaan Penelitian

\begin{tabular}{|c|c|c|c|c|c|c|c|c|c|c|c|c|c|c|}
\hline \multicolumn{15}{|c|}{ Pertemuan, Pokok Bahasan dan Jenis Kegiatan } \\
\hline 1 & 2 & 3 & 4 & 5 & 6 & 7 & 8 & 9 & 10 & 11 & 12 & 13 & 14 & 15 \\
\hline \multirow[b]{2}{*}{$\begin{array}{l}\mathrm{TP} \\
\mathrm{M}\end{array}$} & \multirow{2}{*}{$\begin{array}{c}\text { Tes } \\
\text { Awa } \\
1\end{array}$} & $\begin{array}{l}\text { PB } \\
1\end{array}$ & PB 2 & PB 3 & PB 4 & PB 5 & PB 6 & PB 7 & PB 8 & PB 9 & $\begin{array}{l}\text { PB } \\
10\end{array}$ & $\begin{array}{l}\text { PB } \\
11\end{array}$ & $\begin{array}{l}\text { PB } \\
12\end{array}$ & \multirow{2}{*}{$\begin{array}{c}\text { Tes } \\
\text { Akhi } \\
\text { r }\end{array}$} \\
\hline & & $\begin{array}{l}\text { MPT } \\
\text { MP } \\
\text { M }\end{array}$ & $\begin{array}{l}\text { MPT } \\
\text { MP } \\
\text { M }\end{array}$ & $\begin{array}{l}\text { MPT } \\
\text { MP } \\
\text { M }\end{array}$ & $\begin{array}{l}\text { MPT } \\
\text { MP } \\
\text { M }\end{array}$ & $\begin{array}{l}\text { MPT } \\
\text { MP } \\
\text { M }\end{array}$ & $\begin{array}{l}\text { MPT } \\
\text { MP } \\
\text { M }\end{array}$ & $\begin{array}{l}\text { MPT } \\
\text { MP } \\
\text { M }\end{array}$ & $\begin{array}{l}\text { MPT } \\
\text { MP } \\
\text { M }\end{array}$ & $\begin{array}{l}\text { MPT } \\
\text { MP } \\
\text { M }\end{array}$ & $\begin{array}{l}\text { MPT } \\
\text { MP } \\
\text { M }\end{array}$ & $\begin{array}{l}\text { MPT } \\
\text { MP } \\
\text { M }\end{array}$ & $\begin{array}{l}\text { MPT } \\
\text { MP } \\
\text { M }\end{array}$ & \\
\hline
\end{tabular}

Keterangan:

$\mathrm{TPM}=$ Tes Perseptual Motorik

$\mathrm{PB}=$ Pokok Bahasan

MPT = Model Pembelajaran Tradisional

MPM = Model Pembelajaran Modifikasi

Instrumen yang digunakan dalam penelitian ini ada dua jenis, yaitu instrumen untuk mengukur (tes) keterampilan teknik dasar permainan bola basket untuk anak usia 11 - 13 tahun yang terdiri dari 3 tes keterampilan, yaitu 1) tes dribling, 2) tes passing, 3) tes shooting. Sedang untuk mengetahui tingkat keterampilan motorik yang tinggi dan keterampilan motorik rendah menggunakan tes yang dikembangkan oleh
Gallahue (1987) yang terdiri atas tiga bagian tes yaitu: 1) gerak lokomotor (lari, lompat, gallop, dan skipping), 2) gerak manipulatip (melempar, menangkap, memukul, dan menendang), dan 3) non-lokomotor (meregang, memutar, dan mengayun).

\section{Teknik Analisis Data}

Data yang dikumpulkan selanjutnya dianalisis dan diolah secara statistik 
inferensial dengan menggunakan tekik

faktorial 2 × 2 (Santoso, 2005).

analisis varian atau ANAVA dua jalur atau

\section{Hasil Penelitian}

Keadaan sampel penelitian model pembelajaran dan kemampuan perseptual.

Tabel 1.2. Keadaan Sampel Penelitian Berdasarkan Model Pembelajaran dan Kemampuan Perseptual

\begin{tabular}{|ll|l|l|}
\hline & & Value Label & $\mathrm{N}$ \\
\hline Model & 1,00 & Modifikasi & 40 \\
& 2,00 & Tradisional & 40 \\
Perseptual & 1,00 & Tinggi & 40 \\
& 2,00 & Rendah & 40 \\
\hline
\end{tabular}

Deskripsi rerata dan simpangan baku hasil penelitian disajikan dalam Tabel berikut ini.

Tabel 1.3 Skor Rerata dan Simpangan Baku

\begin{tabular}{|ll|r|r|r|}
\hline Model Pembelajaran & \multicolumn{1}{|c|}{ Perceptual Motorik } & Mean & Std. Deviation & N \\
\hline Model Pembelajaran & Perceptual Motorik Tinggi & 31.20 & 3.592 & 20 \\
Modifikasi & Perceptual Motorik Rendah & 29.35 & 2.681 & 20 \\
& Total & 30.28 & 3.266 & 40 \\
\hline Model Pembelajaran & Perceptual Motorik Tinggi & 31.60 & 2.891 & 20 \\
Tradisional & Perceptual Motorik Rendah & 29.85 & 3.392 & 20 \\
& Total & 30.72 & 3.234 & 40 \\
\hline Total & Perceptual Motorik Tinggi & 31.40 & 3.225 & 40 \\
& Perceptual Motorik Rendah & 29.60 & 3.028 & 40 \\
& Total & 30.50 & 3.237 & 80 \\
\hline
\end{tabular}

Berdasarkan Tabel 1.3 di atas menunjukkan bahwa skor rata-rata perolehan belajar pada semua kelompok sampel berada pada kategori kurang (rentangan rerata skor yang didapat adalah 29 sampai dengan 32 . Setelah perlakuan kelompok siswa yang belajar dengan model pembelajaran modifikasi rata-rata hasil tes siswa dengan kemampuan perseptual motorik tinggi $(\mathrm{M}=31.20$; dan standar deviasi $(\mathrm{SD})=3.592)$ lebih kecil daripada rerata skor hasil tes siswa model pembelajaran tradisional $(\mathrm{M}=31.60 ; \mathrm{SD}=$ 2.891). Kelompok siswa yang belajar dengan model pembelajaran modifikasi rerata hasil tes dengan kemampuan perseptual motorik rendah memperoleh nilai rerata $(\mathrm{M}=29.35 ; \mathrm{SD}=$ 2.681) lebih kecil daripada rerata skor hasil tes siswa model tradisional $(\mathrm{M}=29.85 ; \mathrm{SD}=$ 3.392).

Tabel 1.4. Uji Homogenitas

\begin{tabular}{|c|c|c|c|}
\hline$F$ & df1 & df2 & Sig. \\
\hline 1.312 & 3 & 76 & .277 \\
\hline
\end{tabular}

Dari hasil uji homogenitas tampak bahwa semua hasil nilai statistik Levene memperlihatkan harga Fhitung sebesar 1,312 dan signifikansi 0.277 signifikansi yang lebih 
besar dari 0,05. Ini berarti bahwa semua kelompok perlakuan mempunyai kemampuan yang sama atau homogeny sehingga dapat dilakukan pengujian hipotesis.

\section{Interpretasi Hasil Analisis Pengujian Hipotesis}

Tabel 1.5. Rangkuman Hasil Analisis ANAVA Dua Jalur

\begin{tabular}{|l|r|r|r|r|r|}
\hline \multicolumn{1}{|c|}{ Source } & $\begin{array}{c}\text { Type III Sum of } \\
\text { Squares }\end{array}$ & \multicolumn{1}{c|}{ df } & Mean Square & \multicolumn{1}{c|}{ F } & \multicolumn{1}{c|}{ Sig. } \\
\hline Corrected Model & 68.900 & 3 & 22.967 & 2.299 & .084 \\
Intercept & 74420.000 & 1 & 74420.000 & $7.451 \mathrm{E} 3$ & .000 \\
MP & 4.050 & 1 & 4.050 & .405 & .526 \\
PM & 64.800 & 1 & 64.800 & 6.488 & .013 \\
MP * PM & .050 & 1 & .050 & .005 & .944 \\
Error & 759.100 & 76 & 9.988 & & \\
Total & 75248.000 & 80 & & & \\
Corrected Total & 828.000 & 79 & & & \\
\hline
\end{tabular}

a. R Squared $=, 083$ (Adjusted R Squared $=, 047$ )

Berdasarkan hasil analisis pengujian hipotesis varians dua jalur yang diawali dengan merubah hipotesis penelitian ke dalam rumusan hipotesis statistik sebagai berikut:

1. Tidak ada pengaruh hasil belajar keterampilan teknik dasar permainan bola basket antara siswa yang diajarkan dengan model pembelajaran modifikasi dan model pembelajaran tradisional pada siswa sekolah dasar kelas 5 hasil perhitungan statistik adalah Fhitung $=0,405$ dan nilai signifikansi atau nilai $\mathrm{p}=0,526$, ini berarti nilai p lebih besar dari 0,05 .

2. Ada pengaruh hasil belajar keterampilan teknik dasar permainan bola basket antara siswa yang memiliki tingkat kemampuan perseptual motorik tinggi, dan siswa yang memiliki tingkat kemampuan perseptual motorik rendah pada siswa sekolah dasar kelas 5 hasil perhitungan statistik adalah Fhitung $=6,488$ dan nilai signifikansi atau nilai $\mathrm{p}=$ 0,013 . Ini berarti nilai p di bawah 0,05 .

3. Tidak ada pengaruh interaksi antara model pembelajaran dan tingkat kemampuan

perseptual motorik siswa terhadap hasil belajar keterampilan teknik dasar permainan bola basket pada siswa sekolah dasar kelas 5 hasil perhitungan statistik Fhitung $=$ 0,005 dan nilai signifikansi atau $\mathrm{p}=0,944$, ini berarti nilai $\mathrm{p} \quad \mathrm{di}$ atas 0,05 .

\section{A. Simpulan}

Berdasarkan paparan hasil penelitian, dan pembahasan di atas, maka dapat disimpulkan hasil penelitian sebagai berikut:

1. Tidak ada pengaruh hasil belajar keterampilan teknik dasar permainan bola basket antara kelompok siswa yang diajarkan dengan model pembelajaran model modifikasi dan siswa yang diajarkan dengan model pembelajaran tradisional siswa sekolah dasar kelas 5 .

2. Ada pengaruh hasil belajar keterampilan teknik dasar permainan bola basket antara siswa dengan tingkat kemampuan perseptual motorik tinggi maupun tingkat kemampuan motorik rendah siswa sekolah dasar kelas 5.

3. Tidak ada pengaruh interaksi antara model pembelajaran dan tingkat kemampuan perseptual motorik terhadap hasil belajar keterampilan teknik dasar permainan bola basket siswa sekolah dasar kelas 5 .

\section{Daftar Pustaka}

Alnedral, 2005. Spektrum Gaya Mengajar Pendidikan Jasmani. Jurnal Nasional Pendidikan Jasmani dan 
Iти Keolahragaan. Vol. 4, Nomor 3. Diterbitkan oleh Kementerian Negara Pemuda dan Olahraga.

Arikunto, Suharsimi. 2002. Prosedur Penilaian Suatu Pendekatan Praktek. Edisi Revisi V Jakarta. PT. Rineka Cipta. Jakarta.

Ashtiani, Ali Fathi, Salimi Seyed Hossein, Ayubi Manijeh \& Mohebby Hasan Aly. 2007. A Comparison of the Cooperative Model and Traditional Learning on Academic Achievment. Journal of Applied Sciences 7 (1): 137-140.

Barrow, Harold M. Gee \& Rosemary A. 1976. Practical Approach To Measurment In Physical Education. 2nd Edition. Philadelphia: Lea and Febriger.

Boyd, Lara A., Winstein \& Carolee, J. 2006. Explicit Information Interferes with Implict Motor Learning of Both Continuous and Discrete Movement Task After Stroke. Journal of Neurologic Physical Therapy.

Bucher, C. A. 1983. Foundation of Physical Education and Sport. Missouri: Mosby Company.

Cohen, Louis \& Lawrence Manion, A. 1983. Guide to Teaching Practice. 2nd Edition. London: Methuen.

Deroost Natacha \& Soetens Eric. 2006. Perceptual or motor learning in SRT tasks with complex sequence structures. Psychological Research (2006) 70: 88-102 DOI $10.1007 / \mathrm{s} 00426-0196-3$.

Gabard, c Le Blanc E \& Lowy. S. 1987. Physical Education for Children Building.The Foundation, New Jersey: Prentice Hall Inc. Engelewood.
Gallahue, David. L. 1989. Understanding Motor Development Infats, Children. Adolocent. 2nd Edition. Indianapolis: Benchmarj Press. Inc.

Harrow, Anita J. 1972. A Taxonomy of the Psychometer Domain. New York: David Mc Kay Company Inc.

Joyce, B. \& Weil, M. 1986. Model of Teachings. New Jersey: PrenticeHall, Inc.

Kadir, Abdul, Suhaisa. 2002. Perbandingan Pembelajaran Koparatif dan Tradisional terhadap Prestasi, Atribusi, Pencapaian Konsep Kendiri Akademik dan Hubungan Sosial Dalam Pendidikan Perakuan. Tesis Universitas Putra Malaysia, untuk ijasah Doktor Filsafat.

Kerlinger, F. N. 1986. Asas-asas Penelitian Behavioral. Terjemahan oleh Landung R. Simatupang. 1990. Yogyakarta: Gajah Mada University Press.

Lutan, Rusli. 1988. Belajar Keterampilan Motorik Pengantar Teori dan Metode. Jakarta. Proyek Pengembangan LPTK DEPDIKBUD.

Lutan, Rusli. 1993. Pengembangan Model Pentahapan Tugas Gerak untuk Jenjang Pendidikan Dasar. Kajian Teoritis dan Kajian Empirik. Laporan Penelitian. Bandung. FPOK IKIP Bandung.

Magil, Richard. A. 1993. Motor Learning. Concept and Aplication. 4th. Edition. Madisoa, Wisconsin: Brown and Benemark Publisher. 
Mahendra, Agus. 205. Modifikasi Sarana dan Prasarana Pembelajaran Senam Kelas I Sekolah Dasar. Dirjen Dikti: DP3M.

Maula Personal. 2012. Tujuan dan Fungsi Pendidikan Jasmani. (Online), (http//maulaasam.blogspot.com/2012 /_0-01_01 archive.html.diakses 20 April 2012).

Mutohir, Cholik T. 2002. Program Inservice Training Untuk Meningkatkan Kualifikasi Pendidikan Jasmani di Sekolah Dasar. Gagasan-gagasan Tentang Pendidikan Jasmani dan Olahraga. Unesa University Press.

Mutohir, Cholik T \& Lutan Rusly. 1996. Pendidikan Jasmani dan Kesehatan: Dirjen Dikti Depsikbud.

Ngasmain, Supartono. 1997. Modifikasi Olahraga dan Model Pembelajaran Sebagai Strategi Pembinaan Olahraga Usia Dini Bernuansa Pendidikan. Makalah dalam Konferensi Nasional Pendidian Jasmani dan Olahraga. Bandung. IKIP Bandung.

Piccoli, Gabriel., Ahmad Rani. \& Ives Black. 2001. Based Virtual Learning Environment A Research Framework and A Preliminary Assesment of Effectivenes in Basic It Skill training. MisQuarterly. Vol. 25 No. 4. 401-426.

Rachman, Hari, Amirullah. 2003. Pengaruh Model Pembelajaran terhadap Keterampilan Bermain Softball Siswa Sekolah Dasar. Jurnal Nasional Pendidikan Jasmani dan Ilmu Keolahragaan. Vol. 2, No. 2.

Remillard, G. 2003. Pure Perceptual-based Sequence Learning. Journal of
Experimental Phychology: Learning, Memory and Cognition, 29, 518-597.

Sage, George H. 1984. Motor Learning and Control: a Neuropsychological Approach. Dubuque, Iowa: Wm.C Brown Publishers.

Schmidt, Richard. A. 1991. Motor Learning and Performance: From Principles to Practice. Champaign, Illinois: Human Kinetics Publishers.

Siedentop, Daryl. 1994. Sport Education, Quality PE Through Positive Sport Experience. USA: human Kinetics.

Singer, Robert N. \& Dick Walter. 1980. Teaching Physical Education: a System Approach. Boston: Hougton Miffin Company

Sukintaka. 2004. Teori Pendidikan Jasmani Filosofi Pembelajaran dan Masa Depan. Penerbit NuansaYayasan Nuansa Cendekia. Ujungberung Bandung.

Terence, Langton, W. 2007. Applying Laban's Movement Framework in Elementary Physical Education. Journal of Physical Education, Recreation \& Dance. Vol. 78, Iss. 1: pg 17

Thomas, Jerry. R., Thomas, Khaterina T. \& Lee, Amelia. M. 1988. Physical Education for Children: Concepts Into Practice. Champaign, Illinois: Human Kinetics Book.

Tuckman, B. W. 1999. Conducting Educational Research. 5th Edition. Orlando: Harcourt Brance College Publishers.

Walker, Robin. 2004. Primary Physical Education. (Online) (Physical Education - Program of Studies.htm, diakses 21 Juli 2012). 
Werner, S. \& Alricsson, M. 2005. Self-repoted Health, Physical Activity and Prevalence of Complaints in Elite Cross-Country Skiers and Matched Control. Journal of Sports Medicine and Physical Fitnes. Vol. 46 Iss 4, pg 547.

Wuest, D. A. \& Bucher, C.A. 1995. Foundation of Physical Education and Sport. London, New York, Tokyo: Mosby Year Book Inc. 
Tahun XI, No. 20, April 2015 